\title{
From the COMPany TOWN to the InNOvation Zone: Frontiers of Public Policy, the State Action Doctrine, AND THE First AMENDMENT
}

\author{
Bruce Peabody* \& Kyle Morgan**
}

\begin{abstract}
This article draws on the state action doctrine and the case Marsh v. Alabama to evaluate a recent proposal to create an unprecedented public-private partnership in the state of Nevada. In Marsh, the Supreme Court of the United States held that a private citizen was protected under the U.S. Constitution's First and Fourteenth Amendments in distributing religious literature on the sidewalk of a "companyowned" town. We make the case that both the state policy under consideration and a number of political and economic trend lines indicate that the issue central to Marsh remains pressing at the start of our new millennium: what are the circumstances under which concentrated private power amounts to something akin to government authority, thereby implicating the protections of the national Constitution? Our goal in this piece is not to offer an exhaustive or thorough review of the particulars of the "Innovation Zone" bill under consideration, but to consider, in advance, constitutional problems that might arise from granting corporations broad powers traditionally wielded by governments.
\end{abstract}

\section{KEYWORDS}

Constitutional Law, First Amendment, Free Exercise of Religion, Free Speech, State Action Doctrine, Supreme Court

\section{CONTENTS}

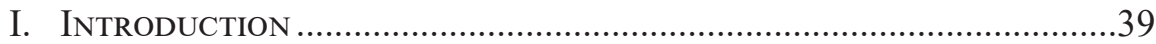

II. State Action and the Twenty-First Century...............................41

III. Four Judicial Standards for Evaluating State Action ...............44

A. The State Association or Cooperation Standard ...........................45

B. The Affirmative Acts Standard ................................................4 47

C. The Coercion Standard .......................................................48

D. The Public Functions Standard.............................................49

* Professor of Government and Politics, Fairleigh Dickinson University, Madison, New Jersey, B.A., 1991, Wesleyan University, Ph.D., 2000, University of Texas at Austin. The authors thank Madelyn Ferrans for her comments on an earlier draft of this article.

** Assistant Professor of Political Science, Francis Marion University, B.A., 2011, Fairleigh Dickinson University, Ph.D., 2020, Rutgers University. 
IV. InNovation Zones in Practice: MaRsh in the Twenty-First Century? .51

A. Finding State Action in the Zone: Judgments A \& B......................52

B. No State Action: Judgments $C \& D$................................................56

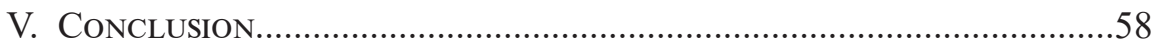




\section{INTRODUCTION}

In his January 2021 State of the State Address, Nevada Governor Steve Sisolak outlined a legislative proposal to foster "Innovation Zones" throughout the state. ${ }^{1}$ As the Governor explained "[n]ew companies creating groundbreaking technologies" would commit to substantial economic and technological development within their identified Zone, in exchange for considerable autonomy and policymaking authority. Indeed, once created, each Zone and its "smart city" population centers would be geographically and legally demarcated from the rest of the state. ${ }^{2}$ According to Sisolak, one company, Blockchains, LLC, had already promised to make "an unprecedented investment in our state to create a smart city in northern Nevada ... making [the state] the epicenter of this emerging industry and creating the high paying jobs and revenue that go with it." 3

The Governor's plans are contingent on the passage of authorizing Innovation Zone legislation. ${ }^{4}$ Under the terms of a draft bill, companies would be eligible for occupying Innovation Zones if they meet certain criteria. Among other requirements, the businesses would need to acquire territory comprising "at least 50,000 contiguous acres of undeveloped land owned or controlled by the applicant" and make "a total capital investment of at least $\$ 250$ million within the territorial boundaries proposed for the Zone" and additional investments "of at least $\$ 1$ billion in the Zone during the 10 years following" its official approval. ${ }^{5}$

In exchange, the investing company would have considerable sway in selecting the members of the Innovation Zone's Board of Supervisors: two of the three members of the Board would come from a list provided by the company. The Board itself would "have the powers and duties of a board of county commissioners" within the Zone. This authority would include being able to levy taxes (with statutory restrictions including bars against taxation on "real property within the zone), hire and fire Zone officers (including the equivalent of county clerks, recorders, sheriffs, treasurers, assessors, auditors, district attorneys, and public administrators), develop and oversee school districts, license businesses, and establish a "justice court" system. ${ }^{7}$

Three months after the Governor's State of the State Address, the Nevada Senate Committee on Legislative Operations decided to review the proposal more carefully, directing it to a bipartisan "special joint committee" for review and commentary. ${ }^{8}$ As State Senator and Majority Leader Nicole Cannizzaro explained,

Full Transcript, Annotations of Sisolak's 2021 State of the State Address, The Nevada INDEPENDENT (Jan. 20, 2021, 2:00 AM), https://thenevadaindependent.com/article/fulltranscript-annotations-of-sisolaks-2021-state-of-the-state-address.

Id.

Id.

See Nevada bill would allow tech companies to create governments, AP STATE NEWs (Feb. 4, 2021).

5 Bill Draft Authorizing the Creation of Innovation Zones, Jan. 31, 2021, https://www. scribd.com/document/493267147/Innovation-Zone-Bill-Draft-update-1-31-2021.

Id.

Id.

Governor Sisolak, legislative leadership announce plans to create special joint committee to study Innovation Zones concept, Nevada Governor STeve SisolaK (Apr. 26, 2021), https://gov.nv.gov/News/Press/2021/Governor_Sisolak_legislative_ 
this step would allow for "additional time to vet this proposal and include critical stakeholders, including tribal leaders, water authorities, environmental groups, labor organizations, economic development authorities, local jurisdictions, and interested tenants." The Governor himself explained that he wanted Nevada citizens to be "enthusiastic" about the Innovation Zone initiative, "not skeptical about a fast-tracked bill." 10

Nevada's Innovation Zone law may never see the proverbial light of day. Nevertheless, the state's proposal to forge a creative public-private partnership raises important legal and constitutional issues that are worth consideringin the context not simply of Nevada's specific initiative and the cognate bills it may directly inspire, but also of more distant, future legislation that pursues some analogous arrangement in which private industry acquires greater formal authority to, in effect, govern those under its jurisdiction. ${ }^{11}$

In this article, we make the case for evaluating the proposed Nevada legislation in light of the venerable "state action doctrine" (which holds that the Constitution, for the most part, only controls the actions of governments and their agents, not private parties), and, more specifically, the precedent of Marsh v. Alabama. ${ }^{12}$ In Marsh, the Supreme Court of the United States held that a private citizen was protected under the U.S. Constitution's First and Fourteenth Amendments in distributing religious literature on the sidewalk of a "company-owned" town. At the time, the Gulf Shipbuilding Corporation owned many of the buildings and much of the infrastructure of Chickasaw, Alabama, and directed a range of traditional government services and operations. ${ }^{13}$

Over the years, the Marsh decision has come to be seen as something of a legal outlier, in part because it has been difficult to think of a twenty-first century parallel to the so-called "company town." ${ }^{14}$ But in the analysis that follows, we make the case that both the Nevada bill under consideration and a number of political and economic trend lines indicate that the issue central to Marsh remains pressing for this new millenium: what are the circumstances under which concentrated private power amounts to something akin to government authority, thereby implicating

leadership_announce_plans/. See generally Ryan Johnston, Nevada presses pause on 'innovation zones,' STATESCOOP (Apr. 26, 2021), https://statescoop.com/nevada-pressespause-innovation-zones/; Legislation introduced to create a joint special committee to review the Governor's Innovation Zones proposal, Nevada Governor Steve Sisolak (May 6, 2021), https://gov.nv.gov/News/Press/2021/Legislation_introduced_to_create_ joint_special_committee to_review_Innovation_Zones_Proposal/.

9 Johnston, supra note 8.

$10 \quad$ Id.

11 Innovation Zones, or Innovation Districts, are not a new concept. See generally Bruce Katz \& Julie Wagner, The Rise of Innovation Districts, A New Geography of Innovation in America, Metropolitan Policy Program at Brookings (May 2014), https://www. brookings.edu/essay/rise-of-innovation-districts/.

12326 U.S. 501 (1946).

13 Shaun Richman, Company Towns Are Still with Us, The American Prospect (Mar. 21, 2018), https://prospect.org/economy/company-towns-still-us/.

14 Marsh itself does not use the term "company town," but instead references a "companyowned town" without providing a specific definition. $C f$., e.g., Lloyd Corp. v. Tanner, 407 US 551, 569 (describing a "company town [as] performing the full spectrum of municipal powers, and st[anding] in the shoes of the State."). 
the protections of the U.S. Constitution? Put more bluntly, this article engages the following question: constitutionally speaking, what do we do with twenty-first century company towns?

Drawing on the (admittedly confusing) state action jurisprudence, including the guidelines set out in the Marsh decision and subsequent case law, we lay out basic standards for evaluating when private action so resembles public authority that it falls under constitutional restrictions. We then apply these standards to the proposed Nevada legislation by superimposing the central facts and legal controversy in Marsh to an imagined Innovation Zone. Our ensuing review delineates four different conclusions judges or other legal analysts might come to in working through the state action problems that would ensue if a visitor to a Zone sought to express her religious views within its confines. We conclude by reflecting upon the broader significance of our argument.

Our goal in this piece is not to offer an exhaustive or thorough review of the particulars of the Innovation Zone bill. Governor Sisolak's original policy proposal may well undergo (substantial) revision, be tabled, or otherwise end up interred in the legislative graveyard. But we invoke the bill's specific language and underlying ideas to put broader constitutional issues (especially concerning the application of the First Amendment to private citizens within privately held enterprise and innovation zones) into the foreground. Whatever the fate of the Nevada Zone program, we think it likely that the challenges it presents will recur in the future in different venues or forms.

\section{State Action And the Twenty-First Century}

Beyond the specific prompt of the Nevada Innovation Zone proposal, four trends lead us to think that the problem of the "company town," and the more general puzzle of demarcating the contours of state action, are likely to persist for the foreseeable future, at least in the United States.

First, we simply note that a number of states are likely to face fiscal imbalances (gaps between their revenues and expenditures) and consequent pressures to find new sources of revenue in the years ahead. An audit of the fifty United States by the Pew Charitable Trusts from fiscal years 2004-2018 revealed that New Jersey, Illinois, Massachusetts, Hawaii, Kentucky, New York, and Connecticut suffered budget deficits in at least 10 of the 15 years covered in this span. In some cases these conditions likely arise from "serious structural deficit[s] in which revenue will continue to fall short of spending [in the future] absent policy changes."15

Whether facing entrenched fiscal challenges or not, it seems plausible that some states, not to mention the federal government, will consider innovations in public-private partnerships to tackle budget challenges. Indeed at the federal level, the Trump administration's 2018 "Delivering Government Solutions in the 21st Century" report called for increased "collaboration across the public (Federal, State, and local) and private sectors" to address areas in which "Government is failing to

15 Barb Rosewicz et al., 9 States Struggle With Long-Term Fiscal Imbalances, Pew (Mar. 18, 2020), https://www.pewtrusts.org/en/research-and-analysis/articles/2020/03/18/9states-struggle-with-long-term-fiscal-imbalances. 
fulfill both citizen expectations and stewardship responsibilities." ${ }^{16}$ More explicitly, the plan called for restructuring "the U.S. Postal System to return it to a sustainable business model or prepare it for future conversion from a Government agency into a privately-held corporation." ${ }^{\prime 17}$ This proposal is just one of many under consideration that raise questions about state action that are central to our concerns. ${ }^{18}$

We bolster these general observations about how fiscal challenges will spur the search for new revenue streams with a second claim. The economic and demographic repercussions of Covid-19 are likely to induce policy changes that will surface many of the questions we grapple with in this article. Indeed, some of these innovations are already well underway. As scholars like Richard Florida and Joel Kotkin report, the U.S. response to the pandemic has given rise to fresh thinking about how we regard the relationship between where people live and where (and how) they work. ${ }^{19}$ The Covid-induced shuttering of central business districts in "superstar cities like New York and London," combined with the flexibility offered by online platforms like Zoom have accelerated a measurable population shift from cities to suburbs and rural areas. ${ }^{20}$ Florida and Kotkin argue that this movement "may augur a long-overdue and much-needed geographic recalibration of America's innovation economy" - away from a handful of sprawling metropolitan centers to a wider variety of settings. ${ }^{21}$

Some of this growth has been and will continue to be facilitated by state and local policies impacting such areas as taxation, affordable housing, regulation, land use, available energy, and physical and intellectual infrastructure. Indeed, Florida claims that "we are in the early stages of a new wave of urban policy innovation, which is occurring from the bottom up in [a variety of] cities, our true laboratories of democracy." 22 It seems reasonable to anticipate that some subset of these innovation laboratories will follow the example of Nevada and attempt to forge new relationships between public and private actors, and new institutions that blur traditional government powers with private authority to wield them.

16 Delivering Government Solutions in the 21st Century: Reform Plan and Reorganization Recommendations, https://www.whitehouse.gov/wp-content/uploads/2018/06/GovernmentReform-and-Reorg-Plan.pdf. See also William J. Henderson, End of the Route: I Ran the Postal Service - It Should be Privatized, Wash. Post (Sep. 2, 2001); Chris Edwards, Privatizing the U.S. Postal Service (Apr. 1, 2016), CATO InST., https://www.cato.org/taxbudget-bulletin/privatizing-us-postal-service\#_edn1.

17 Id.

18 See generally Henry Graber, The Big Problem With Little Island, Slate (Jun. 7, 2012), https://slate.com/business/2021/06/little-island-new-york-city-barry-diller-thomasheatherwick.amp (arguing that New York City's Little Island pier is the "apotheosis of a movement toward private control of public parks").

19 Richard Florida \& Joel Kotkin, America's Post-Pandemic Geography: Covid-19 is transforming all types of communities, from big cities to suburbs to rural areas, City Journal (Spring 2021), https://www.city-journal.org/americas-post-pandemicgeography.

20 Id.

${ }^{21}$ Id. Cf., Steve Case, Helping the 'Rise of the Rest' Cities, Wall St. J. (Nov. 26, 2013), https://www.wsj.com/articles/BL-232B-2047.

22 Richard Florida, This Is Not the End of Cities: Both the coronavirus pandemic and the Black Lives Matter movement create opportunities to reshape cities in more equitable ways, Bloomberg CityLab (Jun. 19, 2020), https://www.bloomberg.com/news/ features/2020-06-19/cities-will-survive-pandemics-and-protests. 
The allure of privatization and the impact of the Covid-19 pandemic also find expression in a third factor relevant to our argument: movement in public opinion. Long-term public opinion data has shown a consistent decline in support for government. ${ }^{23}$ At the same time, more recent soundings of the U.S. public point to greater trust in private corporations, especially in responding to the pandemic. ${ }^{24}$ This longitudinal loss of trust in government and increasing (perhaps short-term) confidence in the private sector is arguably reflected in polling from February of 2020 showing that a third of voters said that "American businesses have a responsibility to take positions on political or social issues facing the country." 25

The fourth development that leads us to believe that state action questions will have continued prominence in the future is the ubiquitous use of (privately controlled) social media as the central medium for democratic (and corporate) expression and speech. Former President Donald Trump's aggressive and innovative use of Twitter in campaigning and governing is an especially dramatic, but by no means the first or last display of this phenomenon. ${ }^{26}$ Consider in this regard President Trump's July 2017 Tweets, which appeared to ban transgender individuals from serving in the military, triggering a series of debates within and outside of government concerning whether this communication possessed the full force of law. ${ }^{27}$

Since the most popular platforms for internet communication are hosted and superintended by private companies, this general phenomenon raises a series of questions about the nature of these environments, when they might be tantamount to constitutionally protected public forums, and what are reasonable limits on speech (and speech regulation) in this context. These were among the issues at hand in the litigation sparked by the Knight First Amendment Institute after it brought suit against former President Trump for blocking seven plaintiffs from commenting on his Twitter account. ${ }^{28}$

All of these developments highlight the importance (and difficulty) of demarcating the lines distinguishing public action from private action. Since, in the modern era, political questions tend to become judicial questions, ${ }^{29}$ we think it is

23 See generally Marc Hetherington \& Thomas J. Rudolph, Why Washington Won't Work: Polarization, Political Trust, and the Governing Crisis (2015); Feature: Public Trust in Government: 1958-2021, Pew Research Center (May 17, 2021), https:// www.pewresearch.org/politics/2021/05/17/public-trust-in-government-1958-2021/.

24 Sara Fischer, Axios Harris Poll 100: Corporate trust soars during the pandemic, Axios (Jul. 30, 2020), https://www.axios.com/coronavirus-clorox-amazon-disney-groceriespublic-approval-bb24d50c-f77a-4e2e-ac2e-3760123b8755.html.

25 Carl M. Cannon, 'Woke' Capitalism and the 2020 Election, RealClear Opinion RESEARCH (Feb. 27, 2020), https://www.realclearpolitics.com/real_clear_opinion_ research/woke capitalism.html.

26 See, e.g., Douglas B. McKechnie, Government Tweets, Government Speech: The First Amendment Implications of Government Trolling, 44 SeATtLe U. L. Rev. 69 (2020).

27 See Recent Social Media Posts, 131 Harv. L. Rev. 934 (2018); Jeannie Suk Gersen, Trump's Tweeted Transgender Ban Is Not a Law, THe New Yorker (Jul 27, 2017), https://www.newyorker.com/news/news-desk/trumps-tweeted-transgender-ban-is-nota-law.

28 Biden v. Knight First Amendment Institute at Columbia University, 593 U.S. (2021), 141 S.Ct. 1229 (2021).

29 Alexis De Tocqueville, 1 Democracy in America 280 (Phillips Bradley ed., 1945). Cf. Mark A. Graber, Resolving Political Questions into Judicial Questions: Tocqueville's Thesis Revisited, 21 CоNST. Сомм. 485 (2004) (arguing that important 
advisable to use the proposed Nevada policy as a prompt to consider, in advance, how courts might tackle some of these issues.

\section{Four Judicial Standards for Evaluating State Action}

As indicated, perhaps the most important touchstone for thinking about the constitutional implications of the proposed Nevada Innovation Zones (and other "smart cities" that conjoin public powers with private resources) is the state action doctrine. This legal concept is simultaneously straightforward in its basic exposition and elusive in practice and jurisprudential development - in part because public and private actions are legally intertwined. As Sidney Buchanan notes, on some level "every action engaged in by a private person is either compelled, prohibited, or permitted, i.e., authorized, by the legal system." 30

As a result the state action doctrine has been labeled at various turns as a "mystery," ${ }^{31}$ a "conceptual disaster area," ${ }^{2}$ and "analytically incoherent." 33 The developed case law in this area may actually deepen the theoretical confusion. As Wilson Huhn charitably explains, the "factual circumstances of the state action cases are varied and diverse, and accordingly, the standards that have evolved to resolve these cases are equally varied and diverse." 34

Nevertheless, one can identify several basic principles that rise above this thicket, providing relatively fixed points for assessing when private activity amounts to action by the state, thereby triggering constitutional rights, limits, and responsibilities.

Speaking broadly, the state action doctrine holds that the U.S. Constitution only applies to actions that can "be fairly attributable" to government actors and institutions. ${ }^{35}$ This idea can be traced to a variety of sources including specific provisions of the constitutional text, ${ }^{36}$ original understandings of the Constitution's scope and purposes (as articulated by the founding generation and the framers of the

political questions during the period of the "Jacksonian Presidents" were not resolved into judicial questions).

$30 \quad$ See G. Sidney Buchanan, A Conceptual History of the State Action Doctrine: The Search for Governmental Responsibility (Part II of II), 34 Hous. L. Rev. 665, 724 (1997).

31 Wilson R. Huhn, The State Action Doctrine and the Principle of Democratic Choice, 34 Hofstra L. Rev. 1379, 1380 (2006).

32 Charles L. Black, Jr., Foreword: "State Action," Equal Protection, and California's Proposition 14, 81 Harv. L. Rev. 69, 95 (1967).

33 Gary Peller \& Mark Tushnet, State Action and a New Birth of Freedom, 92 Geo. L. J. 779,789 (2004).

34 Huhn, supra note 31 , at 1388.

35 Lugar v. Edmondson Oil Co., 457 U.S. 922, 937 (1982). The Constitution's obvious explicit exception to the state action requirement is found in U.S. CONST. amend. XIII ("Neither slavery nor involuntary servitude, except as a punishment for crime whereof the party shall have been duly convicted, shall exist within the United States, or any place subject to their jurisdiction").

36 See U.S. Const. amend. I ("Congress shall make no law respecting an establishment of religion, or prohibiting the free exercise thereof; or abridging the freedom of speech, or of the press" (emphasis added)). 
Constitution's amendments), ${ }^{37}$ the Constitution's history and development, ${ }^{38}$ and case law, especially decisions by the Supreme Court of the United States. ${ }^{39}$ With respect to this last category, we can identify four broad standards or benchmarks the Court has used to identify private activities that amount to state action. ${ }^{40}$

\section{A. The State AsSOCIATION OR CoOperation StANDARD}

The first is what we might identify as a state association or cooperation standard (what Buchanan calls the "State Nexus Issue"). ${ }^{41}$ As the Court articulated in Brentwood Academy v. Tennessee Secondary School Athletic Association, "state action may be found...only if...there is such a "close nexus between the State and the challenged action' that seemingly private behavior 'may be fairly treated as that of the State itself." " 42 In essence, private action can be converted into public action with significant state involvement, as might occur through licensing, delegation of political responsibilities, or vesting powers through statutes or other legal

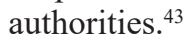

In Lugar v. Edmondson Oil Co., a truckstop operator alleged that a private party (the Edmonson Oil Company) acting jointly with state agents, including a state court clerk and a County Sherriff, had denied him property without due process of law. In evaluating this claim, the Court set out a two-part test that was supposed to give greater clarity for how one determines when a private actor's "deprivation of a federal right [can] be fairly attributable to the State." ${ }^{44}$ Justice White's opinion explained that

First, the deprivation [of a constitutional right] must be caused by the exercise of some right or privilege created by the State or by a rule of conduct imposed by the State or by a person for whom the State is

37 See Huhn, supra note 31, at 1394.

38 See The Heritage Guide to the Constitution 386-8 (Matthew Spalding \& David Forte eds., 2005); Joseph E. Slater, Will Labor Law Prompt Conservative Justices to Adopt a Radical Theory of State Action?, 96 NeB. L. Rev. 62, 69 (2017) ("[t]he basic requirement that the Constitution limit the acts of the state but not acts of private parties...was established in the nineteenth century).

39 See, e.g., Barron v. Baltimore, 32 U.S. 243 (1833) (finding that the Bill of Rights applies only to the federal government not state governments).

$40 C f$. Huhn, supra note 31, at 1382 (arguing that "that the state action doctrine is actually not one doctrine, but four related strands of doctrine); Buchanan, supra note 30, at 345352 (identifying six categories of state action cases).

41 Buchanan, supra note 30, at 346-47. See also Burton v. Wilmington Parking Auth., 365 U.S. 715, 725 (1961) ("[t]he State has so far insinuated itself into a position of interdependence with [a privately held restaurant] that it must be recognized as a joint participant in the challenged activity, which, on that account, cannot be considered to have been so 'purely private' as to fall without the scope of the Fourteenth Amendment"); Moose Lodge v. Irvis, 407 U.S. 163, 177 (1972) (the Pennsylvania Liquor Control Board's regulations do not "sufficiently implicate the State in the discriminatory guest policies of Moose Lodge to make the latter 'state action'...").

42531 U.S. 288, 295 (2001) (quoting Jackson v. Metro. Edison Co., 419 U.S. 345, 351 (1974)).

43 Huhn supra note 31, at 1388.

44 Lugar, 457 U.S. at 923. 
responsible...Second, the party charged with the deprivation must be a person who may fairly be said to be a state actor. This may be because he is a state official, because he has acted together with or has obtained significant aid from state officials, or because his conduct is otherwise chargeable to the State. ${ }^{45}$

The Court, applying this test, found that Lugar was eligible to sue for damages related to incursions on his constitutional rights since the Edmonson Oil Co. had "obtained significant aid from state officials." 46

Almost a decade later, Edmonson v. Leesville Concrete Company ${ }^{47}$ elaborated upon these guidelines, especially by providing a further explanation of the second prong of the Lugar test (requiring that a private party "may fairly be said to be a state actor"). Leesville Concrete found that a private company became a state actor (responsible for upholding the Equal Protection Clause of the Fourteenth Amendment) when it took part in the jury selection process for a civil trial. Justice Kennedy's opinion explained that "[w]ithout the direct and indispensable participation of the judge, who beyond all question is a state actor, the peremptory challenge system would serve no purpose." ${ }^{48}$ The opinion went on to say that the Court's precedents "establish that, in determining whether a particular action or course of conduct is governmental in character" a judge must consider "the extent to which the [private] actor [causing constitutional injury] relies on governmental assistance and benefits... and whether the injury caused is aggravated in a unique way by the incidents of governmental authority." 49

How clear are these legal principles? While it does not seem especially difficult to conclude that private parties participating in the jury selection process are subject to the same constitutional constraints that bind government lawyers and judges, other cases show the ambiguities inherent in applying these and other judicial precedents. ${ }^{50}$ In Blum v. Yaretsky, the Court determined that a private nursing home was not covered within the scope of state action despite being "extensively regulated" by the federal government. ${ }^{51}$ Subsequently, in San Francisco Arts \& Athletics v. United States Olympic Committee, the Court found that the U.S. Olympic Committee (USOC), a federally created private corporation, was not bound by the state action doctrine even though federal law chartered the organization, mandated annual reports to Congress "on its operations and expenditures of grant moneys," and governed such matters as how the USOC could amend its constitution ("only after providing an opportunity for notice and hearing") and how its membership should be comprised.52 As the

\footnotetext{
Id. at 937. See also Buchanan, supra note 30, at 416-18.

Lugar, 457 U.S. at 937.

500 U.S. 614 (1991).

Leesville, 500 U.S. at 624.

49 Kennedy's opinion went on to consider a third criterion (discussed in greater detail below): "whether the actor is performing a traditional governmental function..." Id. at 621.

50 See generally Terri Peretti, Constructing the State Action Doctrine, 1940-1990, 35 LAW \& Soc. INQ. 273 (2010).

51457 U.S. 991, 1004, 1011 (1982). Cf. Jackson, 419 U.S. at 350 ("The mere fact that a business is subject to state regulation does not by itself convert its action into that of the State for purposes of the Fourteenth Amendment") (citations omitted).

52483 U.S. 522 (1987).
} 
Blum and Olympic Committee opinions suggest, the Court does not readily extend constitutional restrictions on private actors and organizations - even when they are extensively regulated and supported by the state.

Conversely, even for obviously governmental actors, the reach of state action can be stopped by relatively modest private barriers or legal circuit breakers. Thus, $N C A A v$. Tarkanian found that a public university's suspension and demotion of a public employee (basketball coach Jerry Tarkanian) did not amount to state action. ${ }^{53}$ In the Court's judgment, in sanctioning Tarkanian, the University of Nevada, Las Vegas (UNLV) was merely responding to the investigation, fact finding, and penalties imposed on the school by the National Collegiate Athletic Association (NCAA), a private "unincorporated association of approximately 960 members, including virtually all public and private universities and 4-year colleges conducting major athletic programs in the United States." ${ }^{4}$ The Court found that the "NCAA cannot be deemed to be a state actor on the theory that it misused power it possessed by virtue of state law" because it sat as a national body composed of public and private participants. ${ }^{55}$ Consequently, Tarkanian did not prevail in arguing that his Fourteenth Amendment due process rights had been violated by the state of Nevada's role in creating and imposing his NCAA suspension. ${ }^{56}$

\section{B. THE AFFIRMATIVE ACTS STANDARD}

Besides looking to the direct or implicit nexus between a private actor and the state, a second, and admittedly overlapping consideration the Court turns to in state action cases is what we might label an affirmative acts standard. As Huhn explains, in assessing whether the government's relationship with private individuals or organizations creates state action, courts look to "affirmative acts" by government rather than "failures to act." 57 The Court's opinion in Blum noted that governmental tacit "approval of or acquiescence in the initiatives of a private party is not sufficient to justify holding the State responsible for those initiatives." 58 Some more proactive decision is needed to turn something into state action.

The affirmative acts standard was at the heart of the famous civil rights case Shelley v. Kraemer. ${ }^{59}$ In Shelley, the owners of property subject to a racially restrictive covenant sought to enforce these provisions (and prevent the Shelleys, a Black family, from acquiring the property) through use of the courts. But in a unanimous opinion, the Supreme Court denied this request as comprising state action and a violation of the Fourteenth Amendment's Equal Protection Clause. Racially restrictive housing covenants do not give rise to state action and challenges

488 U.S. 179 (1988).

Id. at 183 .

Id. at 192.

56 Id. at 193 (finding that the NCAA Collegiate Athletic Association is not a state actor). Cases like Tarkanian help us to see that state action claims face many obstacles under today's doctrine. See Slater, supra note 38, at 75.

57 Huhn, supra note 31, at 1385.

58 Blum at 1004-05. Cf. Buchanan, supra note 30, at 762 (There is a "wide range of private activities that the legal system permits to occur but with respect to which government participation does not extend significantly beyond the 'mere' act of permission."). 
under the Fourteenth Amendment "[s]o long as the purposes of those agreements are effectuated by voluntary adherence to their terms" by private parties. ${ }^{60}$ But active "judicial enforcement of private agreements" provided a sufficient basis for a state action claim, and covenant restrictions based on race denied the Shelley family their constitutional guarantee of "equal protection of the laws."

The courts have sounded similar and perhaps even clearer notes about the necessity of the "action" component of state action in other cases. Thus, in Flagg Bros., Inc. v. Brooks the Court affirmed that it "has never held that a State's mere acquiescence in a private action converts that action into that of the State." 62

\section{THE COERCION STANDARD}

A third analytic guidepost, appearing (somewhat intermittently) in state action jurisprudence involves considering whether the state has leveraged private behavior through coercion or encouragement. This coercion standard builds on the idea that when the state merely authorizes a private party to engage in behavior or pursue a course of action it does not create state action. Instead, the courts require either a more involved and ongoing, cooperative relationship (or state nexus) or private behavior that is induced by government incentives or pressure. As the Court stated in Jackson v. Metro. Edison Co. (echoing Shelley), the mere "exercise of...choice allowed by state law" does not create state action "where the initiative comes from... [private parties] and not from the state. ${ }^{\prime 63}$ On the other hand, as Huhn notes, "where the government coerces, encourages, or influences one individual to invade the rights of another, it is state action." ${ }^{64}$ Thus, in Reitman v. Mulkey, the Court supported the judgment of the California Supreme Court in finding that a state referendum on the sale, leasing, and rental of property violated the Equal Protection Clause insofar as it would "significantly encourage and involve the State in private discriminations." ${ }^{65}$

As mentioned previously, the rise of "big tech" and social media has further complicated this analysis of what comprises state action. Privately held social media websites and "apps" (applications) have become de facto public forums, at least for online communication and expression. But new rules or parameters placed on these companies and platforms by legislatures and other regulators invite us to consider whether the nexus between public authority and private power establishes state action through association or coercion. Consider the example of Florida which passed a "Big Tech" law in May 2021 that would impose $\$ 100,000$ fines on certain social media companies for removing statewide political candidates from their online platforms, and $\$ 10,000$ fines for other removed candidates. ${ }^{66}$

\footnotetext{
$60 \quad$ Id. at 13 .

61 Both Buchanan and Slater question whether Shelley still stands for the general proposition that judicial enforcement of private contracts and sales agreements gives rise to state action, or whether subsequent case law has substantially narrowed its application. See Slater, supra note 38, at 75; Buchanan, supra note 30, at 709.

62436 U.S. 149, 164 (1978).

63 Jackson, 419 U.S. at 357.

64 Huhn, supra note 31, at 1389 (emphasis added).

65 Reitman v. Mulkey, 387 U.S. 369, 381 (1967).

66 Steven Lemongello \& Gray Rohrer, DeSantis Signs Big Tech Censorship Bill,
} 
Again, identifying a more or less discrete coercion standard for state action does not resolve how we ascertain or define the necessary level of influence, pressure, or encouragement that turns private action into public action. In many instances, these issues are difficult, and the Court's conclusions and judgments are not self-evident. In Rendell-Baker v. Kohn, for example, the Court declined to identify a private school as a state actor even though a state body (the State Committee on Criminal Justice) needed to approve some of its hiring decisions and "public funds accounted for at least $90 \%$ [of the school's operating budget], and in one year 99\%." ${ }^{97}$

\section{The Public Functions Standard}

A fourth and final standard the Court has often looked to in evaluating state action is whether a private organization or individual engages in or contributes to distinctive government activities or public functions. Returning to Marsh, the Court found that a privately held town was subject to the protections of the Constitution because it possessed "all the characteristics of any other American town." ${ }^{68}$ As the Court elaborated,

The property consists of residential buildings, streets, a system of sewers, a sewage disposal plant, and a "business block" on which business places are situated. A deputy of the Mobile County Sheriff, paid by the company, serves as the town's policeman ...[Merchants and residents] make use of a company-owned paved street and sidewalk located alongside the store fronts in order to enter and leave the stores and the post office...In short, the town and its shopping district are accessible to and freely used by the public in general, and there is nothing to distinguish them from any other town...except the fact that the title to the property belongs to a private corporation. ${ }^{69}$

Such an emphasis on how a corporation or business has assumed government operations, responsibilities, or powers necessarily shifts our attention away from the state's behavior to that of a private party.

Like other areas of state action jurisprudence, the courts have not been clear or consistent in how they understand this public functions argument or what tools we need to apply it. Perhaps most obviously, private action becomes public action when it effectively replaces the historical operations of the state, including when a private actor engages in "public functions that have heretofore been exclusively performed by government." 70 This orientation is again evident in Marsh. In providing law enforcement through a privately paid deputy, the Gulf Shipbuilding Corporation was assuming one of the quintessential roles of the organized state. ${ }^{71}$

Despite Constitutional Concerns, Orlando Sentinel (May 24, 2021), https:// www.orlandosentinel.com/politics/os-ne-desantis-signs-big-tech-bill-20210524dvycnrscjjbfnnh7vbs3wimv5q-story.html.

${ }_{67}$ Rendell-Baker v. Kohn, 457 U.S. 830, 832 (1982).

68 Marsh, 326 U.S. at 502.

69 Id. at 503 .

70 Huhn, supra note 31, at 1389-90.

71 See Max Weber, From Max Weber: Essays in Sociology 78 (1958) (identifying the 
In Manhattan Community Access Corp. v. Halleck, Justice Kavanaugh's majority opinion emphasized that "to qualify as a traditional, exclusive public function within the meaning of our state-action precedents, the government must have traditionally and exclusively performed the function." 72 Whether Justice Kavanaugh's statement represents a new judicial rule or simply an interpretation of existing doctrine, it is unclear precisely how his two standards ("traditionally" and "exclusively") work together. While the imposition of income tax would seem to be an "exclusive" power of government, it may not be a "traditional" power in the U.S., given that it was only authorized at the national level with the ratification of the Sixteenth Amendment in $1913 .{ }^{73}$ On the other hand, while the power of courts to resolve cases and controversies appears to be a "traditional" government power, the rise of Alternative Dispute Resolution via non-governmental third parties subverts any claim that the judiciary has an "exclusive" hold on this public function. ${ }^{74} \mathrm{In}$ short, it isn't obvious whether privatizing customary state operations (in such areas as taxation, dispute resolution, and even in providing basic security) pass, fail, or undermine the Kavanaugh test.

In any event, whatever its judicial formulation, an historical or traditional "public functions" approach does not give much guidance when it comes to relatively new (or more controversial) aspects of government performance or policy. Is coordinating climate change policy a distinctive or signature public activity? How about regulating health care insurance markets?

In a subset of pertinent cases, judges emphasize that private action becomes constitutionally protected state action when it occurs in a space or locale where the public has general access (or a reasonable expectation of access). Again, Marsh is explicit on this point: "The more an owner, for his advantage, opens up his property for use by the public in general, the more do his rights become circumscribed by the statutory and constitutional rights of those who use it." 75

In still other instances, the courts note that private action and organizations become subject to the Constitution when they become an intrinsic part (or a potential veto point) of government operations. Thus, in the "white primary" case of Terry v. Adams, the Court ruled that an ostensibly private Texas county political organization, the "Jaybird Democratic Association or Jaybird Party" could not exclude Blacks from participating in its elections because doing so would effectively undermine the state's fair and free "election machinery." 76

state as the entity possessing a "monopoly of the legitimate use of physical force within a given territory") (emphasis in original).

72587 U.S. _ (2019), 139 S.Ct. 1921 (2019) (emphasis in original).

73 U.S. CONST. amend. XVI.

74 See Sarah Staszak, No Day in Court: Access to Justice and the Politics of Judicial RETRENCHMENT (2015).

75 Marsh, 326 U.S. at 506. Cf. Republic Aviation Corp. v. Labor Board, 324 U.S. 793 (the National Labor Relations Act does not allow employers to prohibit solicitation by employees outside of working hours but on company property). But see Cyber Promotions v. America Online, 948 F. Supp. 436, 442 (E.D. Pa. 1996) (America Online is not required to provide free speech protections to its users even though it has opened up its servers to the general public).

76 Terry v. Adams, 345 U.S. 461, 466 (1953). See also Smith v. Allwright, 321 U.S. 649, 663 (1944) (a political party's primary election is state action); Peretti, supra note 50, at 276 (discussing the "white primary" cases); Marsh, 326 U.S. at 506 (musing that a 
These different takes on the public functions standard are not exclusive or incompatible. But they often entail distinct analyses of legal sources: historical or inductive review of the customary operations of governments in some cases, evaluations of the behavior and purposes of private actors in others, and, at times, pragmatic judgments about the facts on the ground.

Before passing on to consider how the four judicial standards for evaluating state action might apply to the issues posed by Nevada's Innovation Zones, we take note of Huhn's observation that there "are two general approaches to applying these various tests." 77 The first is a more formalistic, rule-oriented "approach to state action analysis, separately invoking and applying the various specific tests... for determining whether or not the challenged party is a state actor." ${ }^{.78}$ Alternatively, some judges assume a more holistic, "totality of the circumstances" interpretive approach, culling through the specific facts and circumstances of a case to weigh and evaluate each standard and "the nonobvious involvement of the State in private conduct." 79

For our purposes, we do not find it especially helpful or rewarding to choose between these two interpretive approaches. A thoroughgoing state action analysis of all four standards necessarily requires a careful review of the facts and particulars of a case and requires courts to consider a full range of factors that could turn private action into constitutionally proscribed government action.

\section{InNovation Zones in Practice: Marsh In the Twenty- FIRST CENTURY?}

How can one draw on this jurisprudence to evaluate the Innovation Zone legislation under consideration in Nevada? At first glance, the question seems misguided. In the U.S., the judiciary develops legal doctrine not to assess the advisability or legal status of pending legislation but to render judgment in specific cases and controversies. ${ }^{80}$ We attempt to circumvent this problem by adapting the facts present in Marsh v. Alabama to an imagined Innovation Zone within the state of Nevada.

More than seventy-five years ago, Grace Marsh, a member of the Jehovah's Witnesses, "came onto the sidewalk" of Chickasaw, Alabama, a suburb of Mobile. ${ }^{81}$ As noted previously, a private corporation, the Gulf Shipbuilding Corporation owned the sidewalk along with the roads that connected the town, as well as Chickasaw's "residential buildings, streets, a system of sewers, a sewage disposal plant and a 'business block."

company owning a private highway could not restrict its usage in a manner that "gave it power to obstruct through traffic or to discriminate against interstate commerce").

77 Huhn, supra note 31, at 1391.

78 Id.

79 Burton, 365 U.S. at 722 . Huhn associates the rule-oriented approach with conservative justices and the totality of the circumstances orientation with liberals, and notes that the Court has "vacillated" between these two approaches. Huhn, supra note 31, at 1391.

80 See Robert G. McCloskey, The American Supreme Court 12 (2010).

${ }_{81}$ Marsh, 326 U.S. at 503.

$82 \quad I d$. at 502. 
After Marsh attempted to "distribute religious literature" she was "warned that she could not distribute the literature without a permit and told that no permit would be issued to her." ${ }^{83}$ After she persisted, a deputy sheriff employed by the Gulf Shipbuilding company arrested her under the terms of the Alabama Code "which makes it a crime to enter or remain on the premises of another after having been warned not to do so." ${ }^{84}$ At trial, Marsh argued that applying this statute to her activities violated "her right to freedom of press and religion contrary to the First and Fourteenth Amendments to the Constitution." ${ }^{85}$ But she was found guilty and her conviction was upheld by the Alabama Court of Appeals. The Alabama Supreme Court denied certiorari, declining to review the case. The Supreme Court of the United States reversed and overturned her conviction on the grounds that Marsh's "use of a company-owned" sidewalk open "for use by the public in general" entitled her to "liberty of press and religion" which the company could not curtail. ${ }^{86}$

Again, in order to unpack some of the key constitutional issues posed by the Nevada Innovation Zone proposal, we transpose these basic facts to the twenty-first century. How would courts evaluate a similar case, in which a citizen attempted, against clear company prohibitions, to share her ideas and religious beliefs on the sidewalks of an Innovation Zone?

We divide the resulting possible judgments, and ways of seeing the case, into four groups, represented in Table 1. We see two paths for our hypothetical citizen petitioner to win: 1) where the Innovation Zone and its authorities are deemed to give rise to a state action claim (Judgment A), and 2) under circumstances where the corporate Innovation Zone does not amount to state action (Judgment C). Similarly, we see two scenarios in which the corporation running the Innovation Zone prevails: where 3) one determines that the Zone and its Board meet the state action threshold (Judgment B) and 4) where state action is absent (Judgment D). We consider, in turn, some of the likely arguments and precedents that one might draw upon for each of these determinations.

Table 1: Marsh in the Innovation Zones: Four Potential Outcomes.

\begin{tabular}{|c|c|c|}
\hline Party that Prevails & \multicolumn{2}{|c|}{ Status of the Innovation Zone } \\
\hline & State Actor & Not a State Actor \\
\hline Citizen & Judgment A & Judgment C \\
\hline Corporation & Judgment B & Judgment D \\
\hline
\end{tabular}

\section{A. Finding State ACtion in the Zone: Judgments $A \& B$}

Judgment A (finding state action and ruling for the citizen's First Amendment claims) fits most squarely with the majority opinion in Marsh. Imagine a future corporation acting under the proposed Nevada legislation (or something like it)

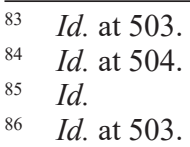


and assuming effective authority over a Board of Supervisors that can exercise the "powers and duties of a board of county commissioners." (through its Board) could impose taxes, hire employees with responsibilities that mimic traditional city workers, and even establish a set of private courts for adjudicating local disputes.

In Marsh, the powers assumed by the Gulf Shipbuilding Corporation fell short of these rather sweeping authorities. Gulf Shipbuilding owned most of the infrastructure, commercial, and residential properties in Chickasaw, and, as noted, employed the town's sole law enforcement agent. But the Alabama Corporation did not directly control the educational system, ${ }^{88}$ the judiciary, ${ }^{89}$ and licensing, taxation, and regulatory powers ${ }^{90}$ - all of which would be assumed by Innovation Zone companies according to the Nevada draft legislation. Just as the companyowned "business block" in Chickasaw, Alabama was functionally equivalent to "any other town," an Innovation Zone would resemble a small city, with the caveat that a Zone would have the discretion to possess a near monopoly on public and private functions within its jurisdiction. This discretion is important as Section 20 of an early version of the legislation allowed for the Board of the Innovation Zone to enter into (or terminate) agreements with any local government in the state, including the county in which the Zone exists, to share responsibilities, officers, and duties. If the basic Marsh holding "that under some circumstances property that is privately owned may, at least for First Amendment purposes, be treated as though it were publicly held" remains good law, it appears easy enough to extend this logic to our imagined Innovation Zone.

Once the Innovation Zone Board and the territories under its control fall under the aegis of state action, one can find abundant precedent to then establish that a citizen's right to distribute literature and share her (religious) views is central to our cherished constitutional protections. ${ }^{91}$ As Marsh explained,

\footnotetext{
[t]he managers appointed by [a] corporation cannot curtail the liberty of press and religion of [the] people consistently with the purposes of the Constitutional guarantees, and a state statute, as the one here involved, which enforces such action by criminally punishing those who attempt to distribute religious literature clearly violates the First and Fourteenth Amendments to the Constitution..$^{92}$
}

Viewed through the lens of the four standards enunciated earlier, this conclusion (Judgment A) is best supported by the "public functions" standard. While Innovation Zones would need to be authorized by state statutes like the one under consideration in Nevada, such legislation, on its own, does not obviously entangle government in the work of the Zone or amount to coercing corporations to take on governance tasks. ${ }^{93}$ Under the proposed legislation, Innovation Zones are only approved after a

Bill Draft, supra note 5.

Id. at Section 24.

Id. at Section 19.

Id. at Section 20.

See, e.g., Hague v. Committee for Industrial Organization, 307 U.S. 496 (1939).

Marsh, 326 U.S. at 508.

93 Obviously, different facts could change the relationship. If Innovation Zones within a 
company designee "submits an application" and the corporation invests substantial resources in the proposed Zone. What makes Innovation Zones like Chickasaw, and what makes them akin to municipal governments, is that they do "not function differently from any other town." 94

The case for applying Marsh analysis to twenty-first century Innovation Zones, and finding them constitutionally comparable to twentieth century company towns is rather compelling. But is there a sensible argument for arriving at what we have described as Judgment B? Once one determines that a company directing activities in the Innovation Zone is a state actor, is there a plausible claim that would allow the Zone's Board to prevail in a dispute with a citizen asserting constitutional rights like free speech and freedom of religion?

To begin with, one might note that the liberties enshrined in the Bill of Rights are not inviolate. Even if the Innovation Zone Board and its agents are cognizable as government actors, they might conceivably overcome First Amendment claims with a demonstration of a "compelling state interest" and otherwise meeting the test of strict scrutiny. ${ }^{95}$ Imagine, for example, that instead of a single religious demonstrator, a gathering of hundreds of protestors occupied the sidewalks of an Innovation Zone for weeks. If one further stipulates that the Zone in question has contracted with the Department of Defense to build a critical military technology (during an active war), it is not farfetched to construct national security considerations that might overcome the free speech and free exercise rights of ordinary citizens, especially considering the Court's historic sympathy to security concerns during periods of international conflict, strife, and declared or de facto war. $^{96}$

Perhaps more plausibly, even after ascertaining that an Innovation Zone qualifies for state action, a judge might still turn to a public forum analysis to determine the extent of a citizen's rights to use the Zone's sidewalks, streets, and other locales. ${ }^{97}$ Current doctrine recognizes three classes of government space where individuals might seek to exercise their constitutional civil liberties: traditional public forums, designated forums, and nonpublic forums. ${ }^{98}$

The first category includes those "places which, by long tradition or by government fiat, have been devoted to assembly and debate." 99 These settings hold "a special position in terms of First Amendment Protection," 100 such that the state's

state begin to supply a substantial amount of state revenues, the state association or cooperation standard might well come into play.

94 Marsh, 326 U.S. at 508.

95 See generally Stephen A. Siegel, The Origin of the Compelling State Interest Test and Strict Scrutiny, 48 Am. J. Legal Hist. 355 (2006).

96 See, e.g., Korematsu v. United States, 323 U.S. 214 (1944); Schenck v. United States, 249 U.S. 47 (1919); Abrams v. United States, 250 U.S. 616 (1919), Holder v. Humanitarian Law Project, 561 U.S. 1 (2010). See generally Geoffrey R. Stone, Perilous Times: Free Speech in Wartime: From the Sedition Act of 1798 to the War on Terrorism (2005).

97 See generally Steven G. Gey, Reopening the Public Forum-From Sidewalks to Cyberspace, 58 Оніо Sт. L. J. 1535 (1998); Robert Post, Between Governance and Management: The History and Theory of the Public Forum, 34 UCLA L. Rev. 1713 (1987).

98 Perry Education Association v. Perry Local Educators' Association, 460 U.S. 37 (1983).

99 Id. at 45. See also Cornelius v. NAACP Leg. Def. Fund, 473 US 788, 800 (1985).

100 United States v. Grace, 461 U.S. 171 (1983). 
powers "to limit expressive activity are sharply circumscribed."101 Restrictions on free speech in these contexts are generally limited to "time, place, and manner" regulations or "content-based" exclusions of speech that "serve a compelling state interest and [are] narrowly drawn to achieve that end." 102 In the context of the hypothetical considered here, with protestors or religious adherents on a public sidewalk or street, we seem to have what the Court has identified as "an archetype of a traditional public forum." ${ }^{103}$ However, it is precisely this "public" element that deserves closer scrutiny, a point we return to below.

Designated or limited forums are sites or venues the government chooses to open and identify as public forums, ${ }^{104}$ although this decision may be reversed in the future. For designated forums, unlike traditional public forums, the government may put into place reasonable access restrictions. Thus in Widmar v. Vincent, ${ }^{105}$ the Court allowed a state university to restrict certain meeting spaces to student groups, excluding non-students from using these facilities. Such a distinction opens up the possibility that a court might identify a Zone as a designated public forum and restrict its free speech and free exercise rights to employees or those with permanent residency.

Finally, in nonpublic forums "the state may reserve the forum for its intended purposes, communicative or otherwise, as long as the regulation on speech is reasonable and not an effort to suppress expression merely because public officials oppose the speaker's view." 106

This backdrop helps us to understand that in a case pitting the First Amendment rights of an individual against a corporation's Innovation Zone interests (in, say, protecting property and conducting business), the outcome could well turn on the specifics of the space in which the sought communication or expression takes place or, more broadly, in how we understand the nature of the Zone itself. If the entire Zone can be regarded as a nonpublic forum, dedicated to promoting commerce or technological innovations, it seems possible that a Zone visitor's distribution of religious literature might be reasonably restricted. Indeed, the draft Nevada legislation makes clear at the very outset that its purpose in creating Zones is to yield benefits to the state as a whole and the "general welfare of its inhabitants."107 This may strengthen the argument that the Zone is more akin to a national bank, military base, or state owned utility than a local public park.

Alternatively, given the expanse of the Zone, an evaluating judge might distinguish some "common areas" (sidewalks, streets, parks, shared dining areas) where the First Amendment fully attaches from others dedicated more directly to say, business, production, research, or technology development-not dissimilar to

\footnotetext{
Perry Educ. Ass'n, 460 U.S. at 45.

Id.

Frisby v. Schultz, 487 U.S. 474 (1988).

04 Perry Educ. Ass'n., 460 U.S. at 45.

454 U.S. 263 (1981).

06 Perry Educ. Ass'n., 460 U.S. at 46.

107 Bill Draft, supra note 5, at Section 1.5 (" $[\mathrm{t}]$ he Legislature hereby find and declares that: The diversification of the economy of the State is vitally important to the general welfare of its inhabitants and the fiscal viability of the state. The state must pursue inventive and creative programs... to attract new forms and types of businesses and to foster economic development...”).
} 
other "free speech zones" that have been established by governments. ${ }^{108}$ To some degree, engaging in this inquiry requires finding the right analogy. Is an Innovation Zone like an army base, prison, public library, government-owned power plant, or a hotel that state actors rent for closed meetings? If so, the Zone may well be a nonpublic forum that can be closed to speech and religious expression on the grounds that these activities are outside the core reasons for possessing and using the space in question. On the other hand, if the Zone, or portions of it, are properly regarded as creating a venue "for purposes of assembly, communicating thoughts between citizens, and discussing public questions," 109 the petitioning citizen will likely win against the claims of the corporation and the Zone Board.

In the end, we should not forget that Marsh's majority freely embraced a balancing test between "the Constitutional rights of owners of property against those of the people to enjoy freedom of press and religion." 110 While the opinion notes that free speech, press, and religion offer "a preferred position" in our constitutional order, as soon as one begins to conceive of a Zone (or portions of it) as a limited or nonpublic forum, it becomes easier to imagine circumstances in which property rights (and the Zone's primary purposes) overpower free expression claims, especially where these are better consigned to other environments.

\section{B. No State ACtion: Judgments $C \& D$}

Given this discussion, and the apparent parallel between the Marsh company town and the comprehensive powers of the proposed Innovation Zones, it might be hard to think one could find support for judgments $(\mathrm{C}$ and $\mathrm{D})$ that find no state action in a company's operation of a Zone. But a closer look at the specific arguments in Marsh points to at least one avenue for concluding that a Nevada-style Innovation Zone might not give rise to such a claim.

Again, Justice Black's majority decision in Marsh v. Alabama emphasized the "public functions" standard for recognizing state action. It further provided three reasons for concluding that the Gulf Shipbuilding Corporation's company-owned town was mostly indistinguishable from a traditional municipality governed by public officials.

First, the Court indicated that Chickasaw, in its appearance, layout, and provided services closely resembled a government entity: "there is nothing to distinguish [Chickasaw] from any other town and shopping center except the fact that the title to the property belongs to a private corporation."111 Second and closely related, the Marsh majority emphasized the openness and ease of access of Chickasaw to the general public: the town's business block "serves as the

108 See, e.g., Ralphs Grocery Co. v. United Food and Commercial Workers Union Local 8, 55 Cal. 4th 1083 (2012) (interpreting the California State Constitution to conclude that "common areas" of privately owned shopping malls are public forums since they "generally have seating and other amenities producing a congenial environment that encourages passing shoppers to stop and linger, to leisurely congregate for purposes of relaxation and conversation" and distinguishing these "from areas immediately adjacent to the entrances of individual stores" which offer fewer free speech protections).

109 Hague, 307 U.S. at 515.

110 Marsh, 326 U.S. at 509.

$111 \quad I d$. at 503 . 
community shopping center and is freely accessible and open to the people in the area and those passing through." 112 The third functional argument concerned not the physical characteristics, layout, and operations of the town but citizens' political expectations. The public had a valid "interest in the functioning of the community in such manner that the channels of communication remain free." 113 The only way the citizens of Chickasaw could exercise their full rights as "free citizens of their State and country" and capably "make decisions which affect the welfare of community and nation" was to be "properly informed" with "uncensored" information and open channels of communication and debate. ${ }^{114}$

Justice Black's analysis is worth recapitulating because it is easy to imagine that Nevada, or other state Innovation Zones, would not closely match the Chickasaw profile. The draft legislation under consideration in Nevada stipulates that an Innovation Zone can only be established on " 50,000 contiguous acres of undeveloped land owned or controlled by the applicant... within a single county." 115 Furthermore, the Zone cannot "be part of a city, town, tax increment area or redevelopment area established by law" and already populated with preexisting "permanent residents," and it specifically defines the "innovative technology" that would be considered acceptable as "Blockchain, Autonomous technologies, The Internet of things, Robotics, Artificial intelligence, wireless technology, Biometrics, and Renewable resource technology."116

This context leads to the inference that, unlike "freely accessible and open" company towns like Chickasaw, Nevada Innovation Zones are likely to be somewhat remote, difficult to access, and distinct from more settled communities. Moreover, given the Zone legislation's stipulation that the acquiring company "will incorporate innovative technology throughout the Zone" 117 it also seems plausible that, unlike Chickasaw, the Zone might well operate and look quite different from other population centers. Existing Innovation Zones have sought to reshape cities and communities, at times engaging in large scale renovations and revitalization that remake an existing populated area where people already live and work. The proposed Nevada bill offers even more of a blank slate for urban and business planners, and the community they create might well look unlike traditional towns or settlements.

Of course, even if the Innovation Zone's Board could convince a court that in its appearance, operations, and accessibility the Zone is distinct from an ordinary municipality, the argument might founder on Marsh's public interest argument. After all, shouldn't Zone residents have a right to free and uncensored channels of expression and communication regardless of where they work and live?

But even this contention might not prevail if the corporation could establish that the Zone was primarily a workplace and that its inhabitants had other, more suitable and clearly public venues for their exercise of free expression rights. For example, an Innovation Zone might be less analogous to a Marsh-style company town if its employees lived in a different location (and merely worked in the Zone)

\footnotetext{
Id. at 508 .

Id. at 507.

Id. at 508.

Bill Draft, supra note 5.

Id.
}

117 Id. 
or if they only inhabited the Zone for finite periods before transferring to other areas more permanently.

These arguments might also assume greater force if judges, in the future, take up the suggestion that online and digital platforms might be regarded as constitutionally protected public forums or "common carriers or places of public accommodation." 118 If online chatrooms, social media sites, and accounts owned by public (and private) officials have, in effect, replaced sidewalks, streets and town squares as venues for communication and expression, perhaps company towns no longer have the same responsibility to keep their physical forums open to all in order to ensure that the community's "channels of communication remain free." Stated differently, the new conditions of the twenty-first century may allow us to reconsider Marsh's assumption that "the functioning of the community" requires that an Innovation Zone be recognized as a public entity with a responsibility to allow the "people to enjoy freedom of press and religion" 119 throughout its private property holdings.

It is challenging but possible, therefore, to reason one's way to Judgment Dwhere one concludes that the Innovation Zone and its governing Board are not state actors and, therefore, that a citizen claiming free expression and religious free exercise rights would not prevail. Getting to Judgment C (no constitutional state action but the citizen still wins) would require the additional step of finding rights outside of the federal Constitution to allow a petitioning citizen to secure a favorable judgment. Such rights might be found, for example, in state statutes or a state constitution. ${ }^{120}$

\section{CONCLUSION}

This article makes the case that the state action doctrine and the precedent of Marsh v. Alabama can help us analyze state legislation that would create a unique publicprivate partnership. Given that the specific legislative prompt for this argument may never even pass, it seems incumbent to reflect briefly on the broader implications of our argument.

To begin with, as noted earlier, there are good reasons for thinking that regardless of the fate of the Nevada bill, states (and the federal government) will continue to look for policy innovations that draw on the resources and capacities of private enterprises while raising difficult legal questions about how we draw the line between public and private authority. ${ }^{121}$

In addition, by unpacking the complexity of state action issues posed by Innovation Zones - and the possibility that courts could plausibly draw on existing

18 Biden, 141 S. Ct. at 1226 (2021).

119 Marsh, 326 U.S. at 509.

120 See, e.g., G. Alan TARr, Understanding State Constitutions (2000); Robert F. Utter, The Right to Speak, Write, and Publish Freely: State Constitutional Protection Against Private Abridgement, 8 U. Puget Sound L. Rev. 157 (1985).

121 Beyond this observation, we note that Joseph Slater has speculated that the state action doctrine may become a future battleground for judges seeking "to revive an extraordinarily broad theory of state action" to curtail private-sector union power. Slater, supra note 38 , at 63. 
doctrine to come to quite different judgments concerning the Zones' constitutional responsibilities - we underscore the necessity (and difficulty) of cutting through the tangled jurisprudence in this area. While beyond the scope of this article, it may well be time for a dramatic rethinking of the purposes of the state action doctrine and how courts approach it. Huhn, for example, calls for a reorientation of state action decisions in favor of reinforcing "democratic choice" (that is, "the right of the people to govern themselves"122) rather than making the doctrine about placing a premium on private, "individual freedom" (including our private liberty to ignore constitutional protections). ${ }^{123}$

More generally, we might note that the state action doctrine "matters because it is a core doctrine in our nation's constitutional framework" - an effort to balance three competing values or interests: individual autonomy, federalism, and our commitment to constitutional rights. ${ }^{124}$ Indeed, numerous constitutional provisions place a premium on dividing public and private authority to protect our freedoms and better preserve good government. ${ }^{125}$ A non-exhaustive list includes: the Emoluments clauses, the guarantee of "a Republican Form of Government," the prohibition on "Title[s] of Nobility," the impeachment and removal provisions (which identify "Bribery" as one of two enumerated "high Crimes and Misdemeanors"), and the First Amendment's "establishment" clause. These examples suggest that grasping the parameters of and rationale for U.S. state action is foundational for comprehending not only the public-private divide, but the very basis of American political authority. ${ }^{126}$

22 Huhn, supra note 31, at 1386 .

123 Id. at 1456.

124 Buchanan, supra note 30, at 339-40.

125 For related arguments, see Gordon Wood, The Radicalism of the American Revolution (1993); Akhil Reed Amar, The Constitution Today: Timeless Lessons FOR THE ISSUES OF OUR ERA (2016).

126 See generally Huhn, supra note 31, at 1396 (providing historical examples of how "private individuals and organizations" wielded power over U.S. citizens and their governments). 